\title{
Article
}

\section{Mechanisms of neoliberal resilience: comparing exchange rates and industrial policy in Chile and Estonia}

\author{
Aldo Madariaga* \\ Universidad Andrés Bello, Escuela de Sociología, República 276, Santiago de Chile \\ *Correspondence: aldomadariaga@gmail.com
}

\begin{abstract}
The global financial crisis has stimulated much research about the resilience of neoliberalism. However, concrete mechanisms of neoliberal resilience are yet to be elaborated. This article elaborates such mechanisms by incorporating Amable's notion of institutional hierarchy into Mahoney and Thelen's gradual institutional change theory. In doing this, it provides a dynamic and politically grounded framework to analyze institutional resilience. Neoliberalism is maintained over time because dominant social blocs defend those policies and institutions that they perceive as more favorable to their interests (high-hierarchy institutions), while allowing degrees of freedom in those that matter less (low-hierarchy institutions). Four mechanisms account for the resilience of high-hierarchy institutions: marginal adjustment, solidification, accommodation and compromise. I explore the potential of this framework by comparing the trajectory of two related policy domains, exchange rates and industrial policy, in countries with a long history of neoliberal policymaking: Chile and Estonia.
\end{abstract}

Key words: causal mechanisms, developing countries, institutional change, neo-liberalism, power

JEL classification: P16 political economy, 024 exchange rate, 025 industrial policy

\section{Introduction}

The stability and change of policy regimes is a timeless research topic in political economy. Many efforts have been devoted lately to understand the resilience ${ }^{1}$ of neoliberalism (see

1 'Resilience' here emphasizes adaptation and adaptability in the face of challenges, a meaning typically used in evolutionary geography and ecology. This meaning differs from those used in engineering - capacity to return to an initial state or 'bounce-back' - and in psychology and community research—capacity to cope with adverse situations highlighting 'resistance' and 'survival'. 
especially Schmidt and Thatcher, 2013). The global financial crisis exposed the perils of neoliberalism, leading many to expect a return to Keynesianism or the emergence of a new policy regime. After a short interlude, however, neoliberalism has re-emerged with full strength.

Much research on neoliberal resilience after the crisis has concentrated on ideological explanations (Blyth, 2013; Mirowski, 2013; Schmidt and Thatcher, 2013). However, these works posit that ideas contain the fruits of their own persistence, neglecting a more careful study of political actors and dynamics. As Schmidt and Thatcher (2013, p. 414) conclude, it is difficult to sustain the causal value of ideas without knowing who carries them (i.e. interests) and in what context (i.e. institutions). This is all the more important when studying non-advanced capitalist economies: because institutions are 'born weak', the preferences and distribution of power between different actors are crucial to explain the durability of policy regimes (Levitsky and Murillo, 2013). This article intends to advance in this underanalyzed direction. Now, authors providing a political explanation of neoliberal resilience (e.g. Crouch, 2011; Streeck, 2014) have tended to concentrate on neoliberalism as an international regime and/or its impact on more or less coordinated market economies, instead of explaining the continuity of neoliberal political economies as such. Surprisingly, these works engage only marginally with the vast literature that has studied the causal mechanisms by which policies and institutions are reproduced or changed over time (Pierson, 2004; Streeck and Thelen, 2005; Mahoney and Thelen, 2010). Finally, contemporary debates on causal mechanisms and institutional change have installed the idea that change is pervasive, leaving us with few alternatives to understand continuity (Boas, 2007).

In connection with Amable and Palombarini (2009) and Thelen (2012), I argue that the deficiency to capture processes of institutional resilience, especially under neoliberalism, is connected with a lack of a deeper conceptualization of how interests and politics affect institutional continuity and change. In order to tackle this, in this article I extend Mahoney and Thelen's (2010) theory of gradual institutional change incorporating the notion of 'institutional hierarchy' (Amable, 2003; Amable and Palombarini, 2009). Institutional change, I argue, depends not only on the characteristics of the political context and the rigidity of institutions, but also on the relation between different institutions and the importance dominant social blocs assign to them, i.e. the institutional hierarchy. In doing this I change the focus of research from the persistence or shift of institutions themselves, to those of the socio-political coalitions or dominant social blocs that support them. Introducing the distinction between high-hierarchy and low-hierarchy institutions helps studying 'multiple institutions as a source of both tensions and opportunities' (Pierson, 2004, p. 136) and provides a way to demarcate a division line between winners and losers of parallel processes of change (Mahoney and Thelen, 2010, p. 13). In this context, I identify four mechanisms of change responsible for the resilience of high-hierarchy institutions: altering parameters (marginal adjustment), narrowing interpretation (solidification), and negotiating minor/larger concessions with other social groups (accommodation/compromise).

I show the potential of this framework by comparing the trajectory of two related policy domains, exchange rates and industrial policy, in countries with a long history of neoliberal policymaking: Chile and Estonia. Exchange rate and industrial policies are critical to define

For an analysis of the resilience to neoliberalism under the latter meaning, as opposed to the resilience of neoliberalism here studied, see Hall and Lamont (2013). I thank an anonymous reviewer for these insights. 
the character of policy regimes in non-advanced political economies (Bradford, 1990; ECLAC, 2012). They constitute not only economic policy options, but choices that shape the organization and structure of the political economy as a whole, define the benefits different societal actors receive, and are therefore thought in conjunction when adopting a new developmental regime. In an era when policy alternatives seem to have faded, exchange rate and industrial policies become crucial components of distributional and partisan struggles (Broz and Frieden, 2006; Mukherjee and Singer, 2008; Camyar, 2014). Chile and Estonia constitute poster-children of market reforms, have a long experience with neoliberal policymaking and are conspicuous examples of neoliberal resilience (Weyland, 1999; Taylor, 2006; Buchen, 2007; Bohle and Greskovits, 2007). This article compares them on the basis of a 'most different' design (Seawright and Gerring, 2008, p. 306). This means that on the background of many differences-geographical location, size, past history, party systems, etc.-it looks for common factors that may explain the common outcome of neoliberal resilience. These commonalities refer to the formation of neoliberal social blocs and their interaction with established institutions. ${ }^{2}$ I conceptualize these commonalities as typical mechanisms of neoliberal resilience.

The article is organized as follows. Section 2 develops the proposed analytical framework and elaborates four mechanisms that capture institutional resilience in high-hierarchy institutions. I then operationalize exchange rate and industrial policies in order to empirically identify when a neoliberal policy regime stops being neoliberal. In the third and fourth sections, I use the proposed analytical framework to study the parallel trajectories of exchange rate and industrial policies in Chile and Estonia, showing how the institutional hierarchy between these two policy domains induces different mechanisms of change. The analysis focuses on the politico-institutional dynamics at work at specific turning points and the emergence and changes in dominant social blocs. Data for this exercise comes from literature review, interviews with policymakers and newspaper articles. In the conclusions, I assess the analytical framework and its contribution to understand neoliberal resilience as well as its pertinence to analyze the Chilean and Estonian neoliberal trajectories.

\section{Gradual institutional change and institutional hierarchy}

The past two decades have witnessed a substantial development of theories of institutional change. ${ }^{3}$ In this development, theories of punctuated equilibrium and path-dependency theorizing the alternation between adaptive and radical change, have given place to theories of gradual institutional change. While the former implied the existence of long periods of relative stasis altered by short and rather rare windows of rapid change, the latter put emphasis on the existence of slow and piecemeal processes of change observable through typical mechanisms. The literature on gradual institutional change helped establish the idea that

2 In line with the theoretical aim of this article, the comparative exercise is not confirmatory - which would require to carefully establish theoretically or empirically based expectations and then process-trace the respective causal mechanisms-but exploratory, i.e. it helps to illustrate the anaIytical power of the theoretical framework and provide evidence of the existence of causal relationships leaving their confirmation for future work (Seawright and Gerring, 2008, p. 298). For a confirmatory analysis of Mahoney and Thelen's framework, see Steinlin and Trampusch (2012).

3 See Streeck and Thelen (2005) for an overview. 
Table 1. Gradual institutional change: Conditions and mechanisms (1)

\begin{tabular}{cccc}
\hline & & \multicolumn{2}{c}{$\begin{array}{c}\text { Characteristics of the targeted institution } \\
\text { (barriers to internal change) }\end{array}$} \\
\cline { 3 - 4 } & & High & Low \\
\hline $\begin{array}{c}\text { Characteristics of the political } \\
\text { context (status quo bias) }\end{array}$ & High & Drift & Conversion \\
\hline
\end{tabular}

Sources: Hacker (2005, p. 48), Mahoney and Thelen (2010, p. 19).

institutional change is pervasive, incremental, and always transformative. Drawing on this body of literature, Mahoney and Thelen (2010; henceforth MT) have established the scope conditions for different mechanisms of gradual institutional change to occur (Table 1). These are based on the conjuncture of two factors: the characteristics of the political context,

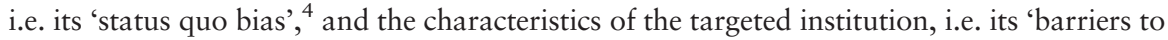
internal change' through alternative meanings and/or variable enforcement.

Now, in their attempt to provide an alternative to punctuated-equilibrium, theorists of gradual institutional change have left us with few analytical tools to actually understand institutional resilience (see Boas, 2007; also Pierson, 2004). I argue that this is partly due to a focus on patterns of change whose agents are societal actors with transformational purposes (Mahoney and Thelen, 2010, pp. 18-23). This focus on transformative processes and agents hides the opposite dynamic, i.e. that of conservative agents aiming at preserving existing institutions and their distributional outcomes. In other words, to understand resilience we need to concentrate on institutional 'winners', and the conditions that determine whether and how much they defend an institution under pressure for change.

\subsection{Institutional hierarchy, continuity and change}

Two ideas form the basis of the theoretical framework of is article. First, that often continuity requires change, even if only cosmetic. Second, that those advocating continuity may actually place themselves at the top of change processes in order to control the outcome. Under this prism, the resilience of neoliberalism depends on the ability of dominant social groups to defend those aspects of a neoliberal policy regime that-in their view-better serve their interests, while allowing degrees of freedom in those aspects that they view as less relevant.

A good way to capture these dynamics is the concept of 'institutional hierarchy' (Amable, 2003; Amable in Crouch et al., 2005; Amable and Palombarini, 2009). If a policy regime and the underlying institutions are the result of a political compromise between groups with different interests, an institutional hierarchy is the order of importance that dominant groups assign to different policies and institutions in terms of attaining their interests. The institutional hierarchy reflects the relative power of different groups within a dominant social bloc, revealing the concrete policy and institutional aspects of the political

4 I have combined MT with Hacker's (2005) categories to better incorporate the concerns of this article. MT restrict the status quo bias of the political context to the existence of veto points, thereby associating continuity with absence of change, i.e. high veto points block change. 
Table 2. Gradual institutional change: Conditions and mechanisms (2)

\begin{tabular}{|c|c|c|c|c|c|}
\hline & & \multicolumn{2}{|c|}{ Institutional hierarchy Low } & \multicolumn{2}{|c|}{ Institutional hierarchy High } \\
\hline & & $\begin{array}{c}\text { Barriers to } \\
\text { internal } \\
\text { change High }\end{array}$ & $\begin{array}{c}\text { Barriers to } \\
\text { internal } \\
\text { change Low }\end{array}$ & $\begin{array}{c}\text { Barriers to } \\
\text { internal } \\
\text { change High }\end{array}$ & $\begin{array}{c}\text { Barriers to } \\
\text { internal } \\
\text { change Low }\end{array}$ \\
\hline \multirow[t]{2}{*}{ Status quo bias } & High & A Drift & B Conversion & $\begin{array}{l}1 \text { Marginal } \\
\text { Adjustment }\end{array}$ & $\begin{array}{l}2(\mathrm{de}) \\
\text { Solidification }\end{array}$ \\
\hline & Low & C Layering & $\begin{array}{l}\text { D Elimination/ } \\
\text { Displacement }\end{array}$ & 3 Compromise & 4 Accommodation \\
\hline
\end{tabular}

Source: Prepared by the author based on Table 1 .

compromise that holds it together and that mediate between societal and political forces inside it (Amable and Palombarini, 2009). Consequently, higher in the institutional hierarchy are those policies and institutions that matter more to attain the interests of hegemonic groups within the dominant bloc, or that are more important in maintaining its underlying political compromise. When the dominant bloc and its hegemony are well entrenched, highhierarchy institutions impose their logic and give a 'dominant tone' to the overall institutional architecture (Boyer in Crouch et al., 2005, p. 367).

In relation with the problem of institutional resilience, two general hypotheses ensue: (a) the stability of an institution depends on its position within the institutional hierarchy, and (b) the dynamic of regime resilience can be captured by the strategic actions dominant groups perform in order to defend high-hierarchy institutions. Incorporating institutional hierarchy as a third dimension to MT's framework provides a way of understanding parallel processes of change as a function of the interests of a dominant social bloc, with continuity or transformation as possible outcomes. Within a particular political context (MT's condition 1) and given certain institutional characteristics (MT's condition 2), change will be more difficult or implemented more cautiously in high-hierarchy institutions (condition 3), where the most powerful groups have vested interests, or where political compromises are more difficult to obtain. Contrariwise, in the same setting, change will be easier in lowhierarchy institutions where dominant groups have less interest and/or where consensus is easier to achieve. In the latter, transformative agents are more likely to take prominence and launch patterns of change of the sort studied by MT. In the former, institutions will show patterns of change associated with the leadership of conservative societal actors.

\subsection{Mechanisms of change in high-hierarchy institutions}

Incorporating institutional hierarchy into MT's framework results in four new mechanisms of change, i.e. those occurring in high-hierarchy institutions, which capture institutional resilience (Table 2). In this subsection, I will describe these mechanisms and illustrate how we can observe them in terms of changes in the institutions themselves and changes in the balance of power.

Institutional resilience reflects the dominant social bloc's ability to defend its interests and policy preferences, and is more likely to occur in a political context biased to the maintenance of the status quo. Where high status quo bias combines with high barriers to internal 
change in high-hierarchy institutions (Table 2, box 1), I expect institutions to undergo marginal adjustment. Marginal adjustment is the closest to an 'adaptive' type of change in the sense that it entails small changes to existing institutions, mainly to improve their performance. In this way, the resulting arrangements maintain the overall policy goals of the hegemonic groups within the dominant social bloc, reinforcing their political clout and the correlation of forces. This may be observed, for example, in the continuity of government posts and influence in policymaking. Signs that marginal adjustment has occurred are the maintenance of the core features of an institution. This includes modifying its parameters or replacing it by another policy instrument that attains the same policy goals.

With high status quo bias but low barriers to internal change, a space for interpretation is open on the dominant social bloc's side. Institutions may thus change through solidification, i.e. a deeper institutionalization of existing rules that narrows the space for enacting alternative interpretations and/or that strengthens enforcement (Table 2, box 2). In terms of balance of power, this is a reflection of dominant groups willing to reinforce or upgrade their position by strengthening institutions closer to their perceived interests. Hegemonic groups may also strategically use solidification to undertake formal changes without changing actual practices (Mahoney and Thelen, 2010, pp. 10-12), e.g. to demonstrate their commitment with reforms to relevant domestic or external pressure groups (Levitsky and Murillo, 2013). In both cases, the existing balance of power is strengthened. Evidence of solidification will be the change of codification of an institution or policy with the result that it is made harder to change, both in terms of veto players and/or alternative meanings. This can be typically achieved by climbing the ladder of institutional formality, from informal to formal rules, from ordinary law to constitutional law.

When the political context allows a more severe challenge to the status quo, the ability of non-hegemonic groups to contest the existing policy regime is higher. Where this combines with low barriers to internal change, dominant groups still retain room for maneuver in the interpretation and enforcement of existing rules. In this context, they may bend the functioning of existing institutions in order to accommodate the interests of those groups pressing for change into the existing political compromise (Table 2, box 4). Consequently, this type of adjustment is characterized by a re-composition of the dominant bloc with the aim of broadening the basis of support for a certain policy regime. This may be reflected, for example, in the incorporation of previously subordinated groups to government, or their increased influence in the elaboration of public policy. Institutionally, a sign of accommodation is that the coherence of a policy regime, in the sense of its congruence in reflecting the interests of dominant groups, decreases (see Amable in Crouch et al., 2005). New institutions may thus be seen as changing the direction of a policy regime.

Finally, where low status quo bias and high barriers to internal change combine (Table 2, box 3), hegemonic groups lose the ability to change how existing rules are interpreted and enforced. In this case, high-hierarchy institutions are threatened and dominant groups may attempt to recompose the political equilibrium in order to negotiate and defend their interests. This case opens the possibility for a compromise, i.e. resilience is achieved at the cost of significant policy concessions, the incorporation of previously critical groups into the dominant bloc, for example, through government positions or concrete policy influence, and/or the dismissal of others. In this case, the institutional and policy mix looks unbalanced as the policy goals of the new institutions openly contradict with those of old institutions or existing ones. 


\section{Measuring neoliberal continuity}

Measuring neoliberal continuity presents two problems. Methodologically, several scholars have warned the difficulty of identifying 'when is change a "real" change' (Streeck and Thelen, 2005, p. 16; see also Boas, 2007), in other words, recognizing when is change reproductive from when it is transformative. Conceptually, neoliberalism has proved malleable over time (Crouch, 2011), making it more difficult to determine when does a policy regime stop being neoliberal. I address these problems in the following way. First, I operationalize exchange rates and industrial policy following Hall's (1993) distinction between policy goals, concrete policy instruments and their parameters. According to Hall's logic, while policy instruments and their parameters can be modified without altering the policy regime at stake, changes in policy goals constitute true regime shifts. Second, following Connell and Dados (2014), I define neoliberalism as a development strategy, and operationalize its exchange rate and industrial policy components closely following the experience of market reforms in non-advanced political economies.

Tables 3 and 4 show the distinction between three policy regimes in exchange rates and industrial policy according to the policy goals they pursue: neoliberal, embedded-neoliberal and developmental. As a development strategy, neoliberalism considers markets as the main allocation device in the economy, and since markets need functioning prices to operate correctly, price stability is a crucial policy goal (Saad-Filho, 2005). This does not necessarily mean reducing state intervention; rather, it means reducing the space for deliberate state intervention trumping correct price signals. Paraphrasing John Ruggie, Bohle and Greskovits (2007) propose the term 'embedded-neoliberalism' to encompass a more pragmatic version of neoliberalism where arms-length arrangements give way to market regulation and state intervention to correct market failures. Following this I consider that a country abandons neoliberalism when policy alternatives fall into a developmental regime, i.e. one characterized by discretionary government intervention favoring certain sectors over others.

Exchange rate (henceforth ER) policy alternatives oscillate between the goals of price stability/credibility and competitiveness. ${ }^{5}$ I classify fixed ER as well as floating ER as neoliberal because their underlying policy goal is to foster price stability/credibility. ${ }^{6}$ This is not only a theoretical distinction. In fact, fixed ERs were used as the core of the most orthodox structural adjustment programs in the developing world (Foxley, 1983; Frenkel and Rapetti, 2010). When the popularity of fixed ER declined, neoliberals pursued as a second-best choice floating ER regimes combined with inflation-targeting frameworks (Mukherjee and Singer, 2008). I classify into developmental regimes those ER instruments that allow monetary discretion without a particular attention to price stability, e.g. managed flotation and multiple ER. Finally, in concordance with Williamson (2002; see also Frenkel and Rapetti, 2010), I have classified 'intermediate regimes' (e.g. crawling pegs, exchange rate bands) aiming at complementing price stability and competitiveness as neoliberal-embedded regimes.

5 Frieden's classification of exchange rate policies by type (fix or float) and level (high or low) generates four possible policy regimes, which in practice become two (Frieden, et al., 2001; Broz and Frieden, 2006): fix-low aiming at price stability and float-high aiming at competitiveness.

6 Although fixed and floating ER are commonly understood as opposite alternatives, Milton Friedman himself viewed them as closely related policy alternatives given their reliance on market mechanisms and their focus on price stability (Hanke, 2008). 
Table 3. Exchange rate regimes

\begin{tabular}{|c|c|c|c|}
\hline $\begin{array}{l}\text { Policy regime } \\
\text { (policy goal) }\end{array}$ & Policy instruments & Description & $\begin{array}{l}\text { Government } \\
\text { discretion }\end{array}$ \\
\hline \multirow[t]{4}{*}{$\begin{array}{l}\text { Neoliberal } \\
\qquad \text { (Price stability) }\end{array}$} & 'Dollarization' & $\begin{array}{l}\text { A country stops issuing its own } \\
\text { currency and adopts a common } \\
\text { currency with other nations or } \\
\text { one issued by some other } \\
\text { country. }\end{array}$ & $\overline{1}$ \\
\hline & Currency board & $\begin{array}{l}\text { Explicit legislative commitment to fix } \\
\text { the nominal ER. Full } \\
\text { convertibility of foreign exchange } \\
(\mathrm{FX}) \text { is guaranteed. }\end{array}$ & \\
\hline & 'Tablita'† & $\begin{array}{l}\text { Authorities pre-commit the future } \\
\text { path of the ER given the } \\
\text { expectations of evolution of the } \\
\text { economy. }\end{array}$ & \\
\hline & Free float & $\begin{array}{l}\text { Commitment of the monetary } \\
\text { authority not to intervene, } \\
\text { leaving the nominal ER to be } \\
\text { determined by the market. }\end{array}$ & \\
\hline \multirow{3}{*}{$\begin{array}{l}\text { Embedded- } \\
\text { neoliberal } \\
\text { (Price stability } \\
\text { and } \\
\text { competitiveness) }\end{array}$} & Adjustable peg & $\begin{array}{l}\text { Authorities commit to defend a } \\
\text { particular parity, but reserve the } \\
\text { right to change it. }\end{array}$ & \\
\hline & Crawling peg & $\begin{array}{l}\text { Authorities peg the local currency to } \\
\text { a foreign currency-or basket- } \\
\text { but adjust the rate gradually over } \\
\text { time in a series of small } \\
\text { corrections. }\end{array}$ & \\
\hline & ER bands & $\begin{array}{l}\text { Authorities set an ER target and } \\
\text { margins for flotation, intervening } \\
\text { to maintain the parity but } \\
\text { allowing flexibility. Margins can } \\
\text { be adjusted. }\end{array}$ & \\
\hline \multirow[t]{2}{*}{$\begin{array}{l}\text { Developmental } \\
\quad \text { (Competitiveness) }\end{array}$} & Managed float & $\begin{array}{l}\text { Authorities are not committed to } \\
\text { defend any particular rate, } \\
\text { intervening at discretion. }\end{array}$ & \\
\hline & Multiple ER & $\begin{array}{c}\text { Authorities impose restrictions on FX } \\
\text { transactions. Different regimes } \\
\text { and/or parities are devised for } \\
\text { different sectors and transactions. }\end{array}$ & + \\
\hline
\end{tabular}

Notes: ${ }^{\dagger}$ This constitutes a special type of crawling-peg ('forward looking') that is closer to the policy goals and operation of a fixed ER than those of intermediary regimes (see Frieden et al., 2001; Frenkel and Rapetti, 2010). Sources: Prepared by the author based on Frieden et al. (2001), Bubula and Ötker (2002), Frenkel and Rapetti (2010). 
Table 4. Industrial policy regimes

\begin{tabular}{|c|c|c|c|}
\hline $\begin{array}{l}\text { Policy regime } \\
\text { (policy goal) }\end{array}$ & Policy instruments & Description & $\begin{array}{l}\text { Government } \\
\text { discretion }\end{array}$ \\
\hline \multirow[t]{2}{*}{$\begin{array}{l}\text { Neoliberal } \\
\qquad \text { (Get prices right) }\end{array}$} & Neutral state & $\begin{array}{l}\text { Industrial policy reduced to freeing } \\
\text { and allowing markets to } \\
\text { function. }\end{array}$ & $\bar{I}$ \\
\hline & Business-friendly & $\begin{array}{l}\text { Regulating markets to improve their } \\
\text { operation, reduction of costs, e.g. } \\
\text { labor market flexibility, tax } \\
\text { reductions. }\end{array}$ & \\
\hline \multirow[t]{2}{*}{$\begin{array}{l}\text { Embedded- } \\
\text { neoliberal } \\
\text { (Align prices) }\end{array}$} & $\begin{array}{l}\text { Horizontal } \\
\text { promotion }\end{array}$ & $\begin{array}{l}\text { Corrects market failures by providing } \\
\text { a common infrastructure that } \\
\text { levels the playfield without } \\
\text { sectoral biases. }\end{array}$ & \\
\hline & Open-economy IP & $\begin{array}{l}\text { Low but not necessary uniform } \\
\text { tariffs, fiscal and credit incentives } \\
\text { for exports, FDI attraction, pro- } \\
\text { export bias. }\end{array}$ & 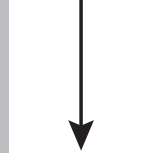 \\
\hline $\begin{array}{l}\text { Developmental } \\
\text { (Alter prices) }\end{array}$ & $\begin{array}{l}\text { Developmental } \\
\text { state }\end{array}$ & $\begin{array}{l}\text { Strategic use of protectionism, } \\
\text { subsidies, and cross-sectoral } \\
\text { transfers. }\end{array}$ & + \\
\hline
\end{tabular}

Source: Prepared by the author based on Kosacoff and Ramos (1999), Schrank and Kurtz (2005).

In terms of industrial policy (henceforth IP), neoliberal regimes aim to impose 'neutrality' to government actions, slashing subsidies and protections and leaving market forces and natural competitive advantages lead sectoral specialization. As the polish minister of Commerce and Trade famously put in 1990, for neoliberals the best industrial policy is no industrial policy. Neoliberal IP also involves state efforts to regulate markets establishing clear rules of the game for markets to operate freely, e.g. including sanctions for monopoly practices, and efforts to reduce costs through 'business-friendly' measures. Embedded-neoliberal regimes are characterized by policy alternatives intended to tackle market failures strictly avoiding sectoral biases. Most policy measures are therefore 'horizontal', e.g. correcting capital markets through soft credit and grants to small and medium enterprises. Similarly, 'open economy' IP (Schrank and Kurtz, 2005) involve state preferences for certain activities but also eschew supporting specific sectors. One example is the promotion of foreign investment using tax exemptions (see also Bohle and Greskovits, 2007). By contrast, developmental IP implies the selection of specific economic sectors for public investment and/or forced crosssector redistribution.

\section{Chile: Neoliberalism with increasing inconsistency}

The Chilean case illustrates the formation of a neoliberal consensus in high-hierarchy institutions (exchange rates) while allowing degrees of freedom in low-hierarchy institutions 
(industrial policy). This reflects recurrent shuffles in the dominant social bloc responding to changes in the balance of power. Three turning points were key to shape this trajectory: a deep financial crisis in 1982-1983, the return to democracy in 1990, and the Asian crisis in 1998-1999.

\subsection{Rise and fall of orthodox neoliberalism}

The neoliberal bloc in Chile was constituted after a bloody military putsch in September 1973. Although a minority faction within the coup coalition, neoliberals became dominant by gradually conquering the key policymaking positions in the following years. The core of the bloc was composed of Junta leader Augusto Pinochet and his loyal collaborators, a group of economists trained at the University of Chicago-later known as the 'Chicago Boys'-and a handful of businessmen with international contacts and their core business in the financial sector. Business groups in the natural-resources export sector (timber, fishing, agriculture) gradually increased their power within the neoliberal bloc as trade liberalization progressed, although remaining in a subordinated position to groups with financial interests (Campero, 1984; Silva, 1996, pp. 137-149). By contrast, business groups relying on state subsidies, mostly in agriculture and manufacturing, were left with little channels of influence despite their continued support for the dictatorship (Campero, 1984; Silva, 1996).

With the constitution of this dominant social bloc, the policy regime moved decisively toward neoliberal alternatives. Exchange rates were placed at the top of the institutional hierarchy being used as the main instrument of structural adjustment (Foxley, 1983; Ffrench-Davis, 2003). The Chicago boys introduced a tablita scheme between 1977 and 1978 and fixed the ER in 1979. Concomitantly, industrial policy began to be rapidly scaled back. Fast trade liberalization swept all kinds of protections, while subsidies and tax exemptions were significantly downsized. As a result, in 1973-1982 expenditures in economic affairs fell from almost $10 \%$ to $2 \%$ of GDP and average tariffs from $80 \%$ to just over $20 \%$ (Figure 1). Additionally, the main agent of the previous Chilean industrialization project, the state promotion agency Corporation for Development (CORFO), was kept only to help in the adjustment process, e.g. to restructure and privatize state-owned companies (Román, 2003, pp. 36-38).

This orthodox neoliberal regime collapsed following a colossal financial crisis in 1982-1983, Chile's deepest crisis since the great crash. The military government faced the alternatives of withstanding deflation or devaluing the exchange rate providing widespread bailouts. The preference for maintaining orthodoxy was continuously stressed (Meller, 1996, p. 218), but bankruptcies had already initiated and the steep 1982 recession made the situation critical. In fact, the crisis reactivated political opposition to the dictatorship who sought to capitalize on the growing social unrest attracting business into a democratizing alliance. Moreover, business sectors led by natural-resource exporters used the threat of democratization to press for greater government responsiveness. Conversely, the rigidity of the exchange rate regime at the top of the institutional hierarchy left little space for internal change. In fact, talk of correcting the ER sparked an intense speculation, making any movement potentially disastrous.

With the political environment open to change, but little room of maneuver to change exchange rates internally (Table 2, box 3), our framework predicts high-hierarchy institutions will undergo a compromise, that is, a substantial re-composition of the dominant bloc and of the respective institutions. Available evidence points in two directions. There is data 


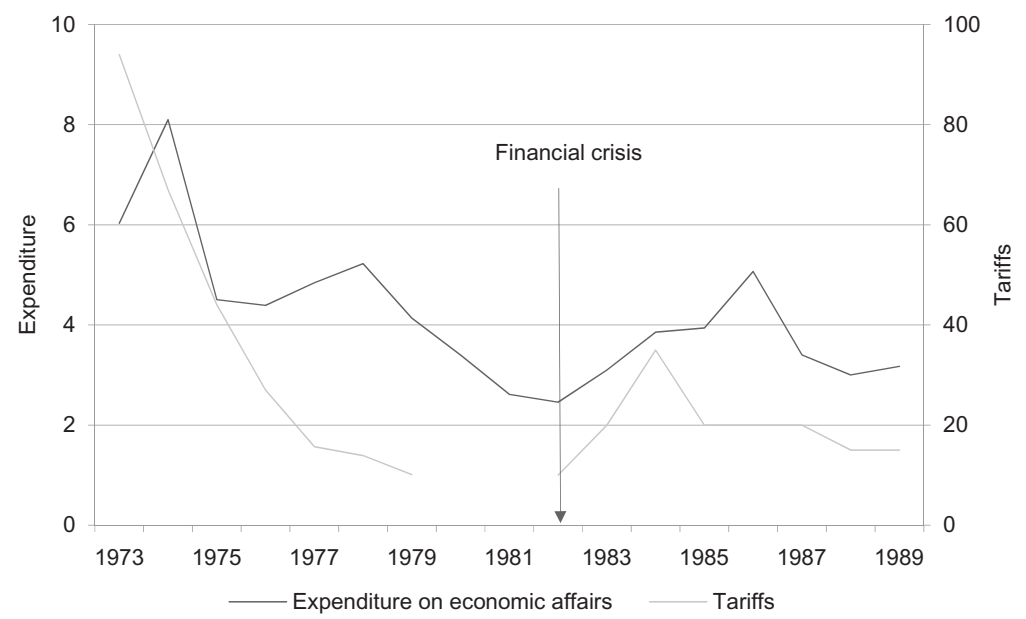

Figure 1. Industrial policy in Chile, 1973-1989. Note: Expenditure refers to percentage of GDP; Tariffs refer to simple averages (1973-1979), and nominal tariffs (1982-1989).

Sources: Wagner et al. (2000) for expenditure; Meller (1996, p. 248) and Ffrench-Davis (2003, p. 119) for tariffs.

that illustrate an incipient compromise mechanism the first 2 years after the crisis. First, hegemonic groups within the dominant bloc fell in disgrace, while subordinate ones came to prominence. The financial sector growth rates plummeted, many of its executives were prosecuted for their responsibility in fraudulent bank lending, and their assets were nationalized, while Chicago Boys in the cabinet were sacked (Silva, 1996). Conversely, Pinochet granted peak employer associations, now dominated by natural-resource exporters, an important role in influencing policy decisions through policy councils and consulting commissions, and contrary to previous practice, appointed business representatives to the key ministries. Pinochet even promoted to cabinet politicians closely associated with protectionist business sectors. In policy terms, this is illustrated by the shift towards a neoliberal-embedded crawling peg ER alternative to help promote export competitiveness.

Under the same political constraints but with lower barriers to internal change in lowhierarchy industrial policy (Table 2, box D), the new groups in the dominant bloc supported policies that were previously seen as 'deviant, aberrant, anachronistic, or "foreign" practices' (Streeck and Thelen, 2005, p. 20) such as tariff increases, protections for selected sectors and sectoral promotion through tax rabates (Figure 1), i.e. embedded-neoliberal policies that displaced previously neoliberal industrial policies.

Around 1985, however, when the political and economic crisis was behind and business had confirmed its allegiance to military rule, Pinochet reversed some of this changes. He sacked from cabinet representatives of the most protectionist business sectors and appointed a new generation of Chicago boys to the key ministries, leaving intact the channels of influence of natural-resource exporters. These changes in the balance of power resemble more an accommodation mechanism than the initial compromise. In policy terms, this reaccommodation did not produce additional changes in high-hierarchy ER as the crawling 
peg was designed in a way not to hurt price stability (Frenkel and Rapetti, 2010, p. 34; Morandé and Tapia, 2002, p. 68), but required a firm commitment that the government would not breach maximum accorded inflation rates (Silva, 1996, pp. 176; 179). In the case of industrial policy, the shift did have the effect of eliminating the most progressive policies (increase in tariffs and selective protections), thereby moderating the initial displacement.

In sum, the terms of the new alliance ensured the continuation of the dictatorship and the neoliberal policy regime in exchange for higher government responsiveness to business interests that were previously subordinated. However, the modification of the initial pattern of change following reshuffles in the balance of power calls for a better consideration of how sequences of change affect institutional change outcomes (Van der Heijden, 2010, pp. 238 239).

\subsection{Continuing neoliberalism under democratic governments}

In 1988, the united center-left opposition defeated Pinochet in a plebiscite that sealed the return to democracy, generating strong fears of policy reversals (Weyland, 1999, p. 69; Silva, 2002, p. 344). However, when the center-left Concertación coalition finally gained the presidency in 1989, the political context was heavily biased to preserving the status quo. In fact, Pinochet imposed a series of institutional reforms-not least a new Constitution-with the explicit aim of blocking future policy changes. The new institutions included strong biases to representation in Congress (a sui generis electoral system designed to favor the right, non-elected senators appointed by the military, supermajority thresholds to change key aspects of the Constitution) and a tutelary role for the Armed Forces. Second, threats of capital strike and of a military backlash derived in the gradual moderation of the economic policy discourse of the center-left Concertación and the leadership of its most conservative factions (Silva, 1996; Taylor, 2006).

Yet, certain aspects of the crawling peg exchange rate policy left some spaces to exploit. In fact, with small changes, e.g. to the devaluation formula or gradually introducing flotation bands, the new government could easily induce a stronger competitive bias and thus move this embedded-neoliberal exchange rate toward the developmental side. With high status quo bias but low internal barriers to change our framework predicts a process of solidifcation of exchange rates, that is, a reduction of possibilities for future change that reinforces the status quo (Table 2, box 2). Available evidence confirms this. First, only a few months before leaving office the military authorities attempted to constrain the monetary policy choices of the new center-left democratic government by introducing a new central bank law ensuring its independence and exclusive focus on price stability (Boylan, 1998). Moreover, they staffed the new monetary policy council with supporters of the military regime, making any change of direction even more difficult. Therefore, despite the ability of the Concertación to negotiate the composition of the Central Bank and the capacity of some progressive Concertación economists within the Bank to introduce a more developmental bias to ER policies (e.g. actually introducing ER bands and capital controls; Ffrench-Davis, 2003), the 1989 Central Bank Law was crucial to ensure that the price stability goal of the ER had precedence over the competitiveness goal once they started to conflict with each other (see below).

In the case of low-hierarchy industrial policy, the high status quo bias and the possibility of open interpretation (Table 2, box B) opened spaces for two opposing forces driving change. First, the more conservative forces within the Concertación coalition pledged to 
continue the policy of free trade inherited from the dictatorship by signing Free Trade Agreements (FTA) and entering the WTO. In parallel, however, the Concertación's more progressive factions used the little space left for industrial policy to seek strategic support from small and medium enterprises (SMEs; Silva, 2002, p. 352; Román, 2003, p. 40). They utilized existing institutions (for example the nearly dead and heavily indebted state promotion agency CORFO) to advance a more coherent framework of industry promotion favoring SMEs through a battery of demand-side subsidies and grants (Román, 2003; Weyland, 1999, p. 76). Although this framework was limited in scope, avoided sectoral interventions and devoted few new resources to industry promotion, some analysts conceive it as the 'most powerful microeconomic toolbox in operation in the Latin American region' (Román, 2003 , p. 59). In other words, the new industrial policies put in movement a process of conversion of the moribund state promotion agencies, especially CORFO. Used during the dictatorship only to help in the privatization and liberalization process, CORFO and other agencies were now 'redirected to new goals, functions [and] purposes' (Streeck and Thelen, 2005, p. 26).

The crisis of fast-growing developing economies at the end of the 1990s reached Chile heightening the inconsistency of the precarious equilibrium between price stability and competitiveness in the high-hierarchy ER policy (Morandé and Tapia, 2002). The economic and political context surrounding the crisis, however, favored the maintenance of neoliberalism once again. In fact, the neoliberal bloc still enjoyed ample veto power thanks to the constraining institutions enshrined in the Constitution. Moreover, the crisis strengthened the power of the more orthodox factions within the dominant bloc. Escaping from the volatility and downturn of commodity prices during the 1990s, business groups in the export sector gradually diversified toward sheltered non-tradable sectors especially privatized public utilities, while the financial sector renewed its strength (Lefort, 2010). Executives from these sectors in charge of the main business associations staged a strong threat of capital strike when Ricardo Lagos from the leftist faction of the Concertacion won the presidential elections in 2000 (Silva, 2002).

In the context of high status quo bias but low internal barriers to change, our framework predicts a new process of solidification (Table 2, box 2) for high-hierarchy exchange rates. Evidence points to the right direction. First, annual ad-hoc inflation targets were replaced by a full-fledged inflation-targeting mechanism with established inflation goals and procedures. This entailed changing the embedded-neoliberal exchange-rate bands for a neoliberal free float exchange rate. Additionally, the government introduced a fiscal rule restricting public expenditures in order to-among other things-constrain the effect of public spending on the ER. The new fiscal rule was initially implemented as a government commitment but was rapidly transformed into a law project and passed in 2006 as the 'Fiscal responsibility Law'. The process was led by the more conservative factions of the Concertación willing to reassert their influence in the context of growing leftist pressures within the coalition (Silva, 2002).

The price neoliberals paid for this further solidification of high-hierarchy institutions was yet another loosening of low-hierarchy industrial policy. The bad performance of the horizontal industrial policy framework, the disappointing growth levels following the Asian crisis, and the arrival of the left-wing of the Concertación to government helped to create a feeling that more selectiveness was needed (Muñoz Gomá, 2001, pp. 29-30; Agosín et al., 2009 , n. 7). Although overall spending levels remained relatively constant and trade openness continued steadily (Figure 2), new programs started to gradually introduce some 


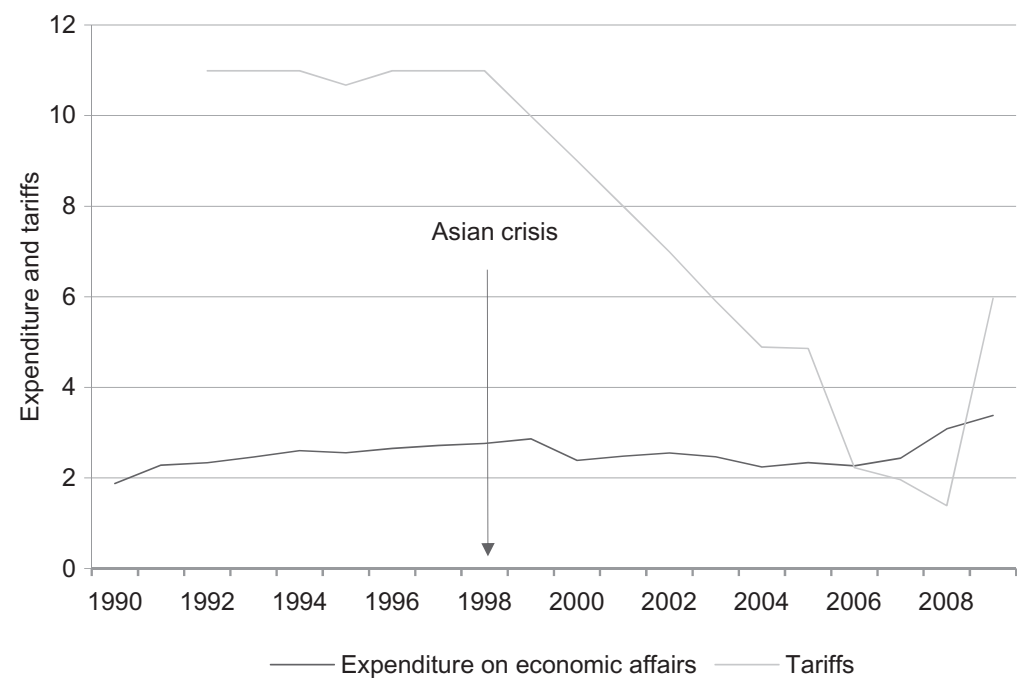

Figure 2. Industrial policy in Chile, 1990-2009. Note: Expenditure refers to percentage of GDP; Tariffs refer to simple averages of affectively applied tariffs (AHS).

Sources: Chilean Budget Directorate (DIPRES) for expenditure; Trade Analysis and Information System (TRAINS) for tariffs.

selectiveness in state intervention thus deepening the previous conversion process. For example, after much struggle the more progressive factions of the Concertación managed to push in 2005 a tax on copper sales to fund higher R\&D expenditures. A new government agency, the National Council of Innovation for Competitiveness (CNIC), was then created to advice the president on how to spend the resources from the new tax. The CNIC conducted a series of studies that recommended that the resources be used to support strategic productive sectors (Agosín et al., 2009). Consequently, CORFO's flagship horizontal programs have been gradually directed to support priority economic sectors (Agosín et al., 2009, pp. 26-27).

In the late 2000s, the Chilean neoliberal regime faced increasing tensions. Among them, exchange rate appreciation heightening the divergence of interests between tradable and non-tradable sectors within the neoliberal bloc, the renewal of social movements and protest events, and the elimination of several institutional constraints. The election of the first rightwing president in more than 50 years in 2010, and the turnover to a center-left coalition including the Communist Party in 2014 are a sign of this state of flux. Following the exposed analysis, continued neoliberal resilience will depend on the ability of the dominant social bloc to defend high-hierarchy exchange rates incorporating new interests into the dominant bloc, thereby allowing degrees of freedom in low-hierarchy industrial policy.

\section{Estonia: a tight neoliberal path}

Estonia shows a trajectory in which the high-hierarchy exchange rate institutions remained largely uncontested, reflecting the consolidation over time of an entrenched neoliberal dominant social bloc. Three turning points helped to sustain orthodox neoliberalism in Estonia: 
an early banking crisis (1992-1994), the effects of the Asian/Russian crises and the context of (European Union) EU accession (1997-2004), and the recent global financial crisis (2008-2010).

\section{1 From Soviet rule to a free market miracle}

The constitution of a neoliberal dominant social bloc in Estonia followed the independence from the Soviet Union, the dissolution of communism, and the new set of economic and political actors that the construction of a democratic polity and a market economy involved (Lauristin and Vihalemm, 1997; Smith, 2001). The Soviet Union's hostility toward Baltic independence and the pro-Soviet demonstrations of a small but vocal group within the large Russian-speaking minority in Estonia helped to forge a tight connection between independence, ethnicity, and economic policy orientations favoring radical reforms (Lauristin and Vihalemm, 1997, pp. 95-97; Smith, 2001; Pettai and Hallik, 2002). Radical reformers became true nation builders by condemning Soviet legacies, rejecting state intervention, and exacerbating strong feelings against the Russian minority who were over-represented in heavy industry. ${ }^{7}$ As a consequence, center-left parties advocating more gradual reforms, some degree of state intervention and the inclusion of ethnic Russians saw their electoral chances among ethnic-Estonians decreased (Smith, 2001, p. 82).

Estonian neoliberals went further in their preference for price stability than their Chilean counterparts, opting for a currency board ER regime. The Estonian Kroon was pegged to the Deutsche Mark and the parity protected by law. Other reforms included quick price liberalization and large-scale privatization. Especially important was the approval in the new Constitution of a balanced budget provision that forced the slashing of state subsidies. Elections for the first parliament after more than 50 years in 1992 gave an ample majority to parties advocating shock therapy, confirming therefore the shift toward a neoliberal policy regime. The new government conducted an aggressive policy of unilateral tariff reductions (Feldmann and Sally, 2002) and rejected any type of selectiveness in state intervention, including free trade zones and tax breaks for foreign investors (Sutela, 2001, p. 19).

The Estonian economy had to withstand an acute banking crisis triggered by the dissolution of the Soviet Union in 1992. Following the first economic reforms in Estonia, private banks went from 5 to 43 in only 5 years (Fleming et al., 1996, p. 4). They exploited loose supervisory rules to generate fast private gains, engaged in excessive lending, high interest rates, and corporate practices that 'bordered illegality' (OECD, 2000, pp. 105-107; Fleming et al., 1996, p. 29). A crisis exploded when Russian banks froze Estonian Banks' foreign exchange deposits, creating a strong credit contraction and a chain of failures. ${ }^{8}$ These problems were exacerbated with the implementation of the currency board in June 1992, which made impossible for troubled banks to get new credit. Prime Minister Mart Laar and Bank of Estonia Governor Siim Kallas announced that no bail-outs would be provided-not even

7 During Soviet domination, authorities encouraged Russian immigration in order to feed the industrialization process. At the end of the Soviet era less than $40 \%$ of the industrial workforce was ethnic Estonian (Pettai and Hallik, 2002, p. 515).

8 Before independence, local branches of the Soviet state banks (precursors of Estonian private banks) sent most of their deposits back to their headquarters in Moscow. In the context of the dissolution of the ruble zone in early 1992, state banks in Moscow froze all assets belonging to nonRussian banks (Fleming et al., 1996, p. 8). 
to state companies under stress-in order to defend the currency board (Fleming et al., 1996, pp. 14; 20; Laar, 2002, pp. 179-181; 187-188).

A look at the conditions underlying this crisis in contrast with Chile's 1982-1983 financial crisis provides a basis to understand the different responses and the ensuing sequences of institutional change. Unlike the Chilean case, the conditions surrounding the Estonian banking crisis greatly favored the maintenance of the status quo. First, the independence process and the ethnic politics dynamic still dominated the prevailing political context, insulating neoliberal reformers from bailout demands. In fact, as some banks were suspected to have ties with Russian mafias, Estonian authorities could resort to nationalistic sentiments to justify rejecting bailouts (Laar, 2002, pp. 188; 191-192). Additionally, the massprivatization process had not yet taken off so there were no special interests to accommodate or compromise with. In contrast with Chile, the state still controlled a majority of the banking system and relatively few depositors were involved in the banking collapse (Fleming et al., 1996, pp. 7; 18). Conversely, a strict institutionalization of the currency board and fiscal spending rules gave no room of maneuver for internal change. In fact, the constitutional constraint on fiscal policy was one of the reasons invoked for the limited policy responsiveness (Fleming et al., 1996, p. 14).

With high status quo bias and little room for alternative rule interpretations (Table 2, box 1), our expectations are for marginal adjustment, that is, small corrections to reinforce the existing policy framework and balance of power. Evidence suggests this was the case. While the currency board remained in place, small parametric changes were introduced to improve its performance: banking licensing was strengthened, new regulatory and supervisory measures implemented, new international accounting standards and stronger capital requirements introduced, and a new Law on Credit Institutions was passed (Fleming et al., 1996, p. 28; OECD, 2000, pp. 106-7). In terms of the emerging neoliberal social bloc, this early banking crisis had crucial consequences. First, marginal adjustment reinforced the performance of the currency board and facilitated the quick development of a large financial sector, e.g. by deepening financial and derivative markets, exchange rate insurances, and swap contracts (Sörg and Vensel, 2000, pp. 128; 132). Second, the decision not to intervene constituted a direct rejection of an alliance with company managers and bank supervisorsi.e. the emerging domestic capitalist class—and an indirect wink to foreign capital (Fleming et al., 1996, p. 26). This was confirmed with the privatization program launched in 1993, which included an explicit bias towards the attraction of Foreign Direct Investment (FDI) (OECD, 2000, pp. 126-36). In fact, between 1993 and 1998 some 31\% of total privatization revenue came from external capital while privatization-related FDI constituted $20 \%$ of all FDI inflows (OECD, 2000, p. 131). Foreign capital flowed to the most dynamic sectors in the raw materials and light industries (forestry and timber, food, textiles; Tiits et al., 2006, pp. 74-81), not to mention public utilities and the financial sector itself. ${ }^{9}$ In 1997 one-third of the Estonian output generating over $50 \%$ of its exports was controlled by foreign capital (Sutela, 2001, p. 19). Finally, the marginal adjustment process was crucial to fix expectations about the commitment of the Estonian authorities to maintain neoliberal orthodoxy in the future (Fleming et al., 1996, pp. 19-20).

9 This calls into question the portrayal of Estonia as an Liberal Market Economy based on its reliance on sectors of radical innovation (Buchen, 2007). 


\subsection{Stabilizing orthodoxy amidst financial woes}

The new dominant social bloc (financial sector and export industries with significant foreign control, right-wing parties in parliament) and the neoliberal institutional hierarchy it supported faced a second turning point with the Asian/Russian crises. Macroeconomic imbalances accumulated during booming economic activity in 1995-1996, sparking fears about the ability of the Estonian authorities to maintain the currency board in 1997 when financial turmoil revamped emerging markets (OECD, 2000; Sutela, 2001).

The political context, however, was highly biased to maintaining the status quo in highhierarchy exchange rates. The Estonian government controlled by the centrist Coalition Party was quick to foreclose any possibility of a devaluation least so of modifying the currency board. Additionally, the popular Reform Party created by the father of the currency board, Siim Kallas, moved to include the maintenance of the currency board in its government program (Baltic News Service, 1999). With a steady support of around 20\% of seats in parliament, the Reform Party managed to form part of all governments since 1995 (with a short interlude in 1997-1998). The maintenance of the currency board was also reinforced with the process of accession to the EU. In fact, given the EU's strong support for monetary arrangements fostering price stability, the maintenance of the currency board was seen as the best way to quickly enter the Eurozone (Feldmann, 2006).

With a political environment conducive to the maintenance of the status quo, and the strict margins for interpretation left by the currency board (Table 2, box 1), our framework predicts that the policy responses were similar to the ones given in 1992, i.e. marginal adjustment. Available evidence supports this. The currency board was confirmed and reinforced through changes such as increased reserve constraints and strengthened liquidity requirements (OECD, 2000, p. 69). These measures served to navigate through the crisis, and reinforce the existing dominant social bloc in its aftermath, especially financial foreign capital. Profiting from low asset prices and bankrupt companies, foreign capital entered massively into the Estonian economy (Eamets et al., 2003, p. 6). As a result, about $85 \%$ of the Estonian banking sector, $90 \%$ of the leasing, and $30 \%$ of the insurance market became concentrated in two Swedish financial groups (OECD, 2000, p. 106; Sutela, 2001, p. 34).

In the case of industrial policy, this context led to the empowerment of groups seeking higher state intervention. The Russian crisis aggravated the problems of agriculture and the food-processing industries, which renewed efforts to obtain trade protections and subsidies (Smith, 2001, pp. 103-106). EU accession gave higher legitimacy to these demands since it required Estonia to raise tariffs in line with EU levels and to implement agricultural subsidies as part of the Common Agricultural Policy (CAP; Smith, 2001, p. 104). Conversely, the mood of EU accession as well as direct pressures from the European Commission for more inclusive ethnic integration laws brought a relaxation of the ethnic cleavage increasing the electoral chances of center-left parties (Lagerspetz and Vogt, 2013). In fact, the center-left Center Party managed to become the biggest party in parliament in 1999 and entered provisional governments in 2003 and 2005. In this context, seeing European Monetary Union (EMU) accession as a major goal, Estonian neoliberals accepted that EU accession implied renouncing to lower-hierarchy features of Estonia's orthodox neoliberal regime like industrial and trade policy (Feldmann and Sally, 2002, p. 99).

Unlike high-hierarchy exchange rate institutions, the political environment in the lowhierarchy industrial policy was therefore more open to change. With little room of maneuver for interpretation given the tightened fiscal spending rules, industrial policy underwent a 


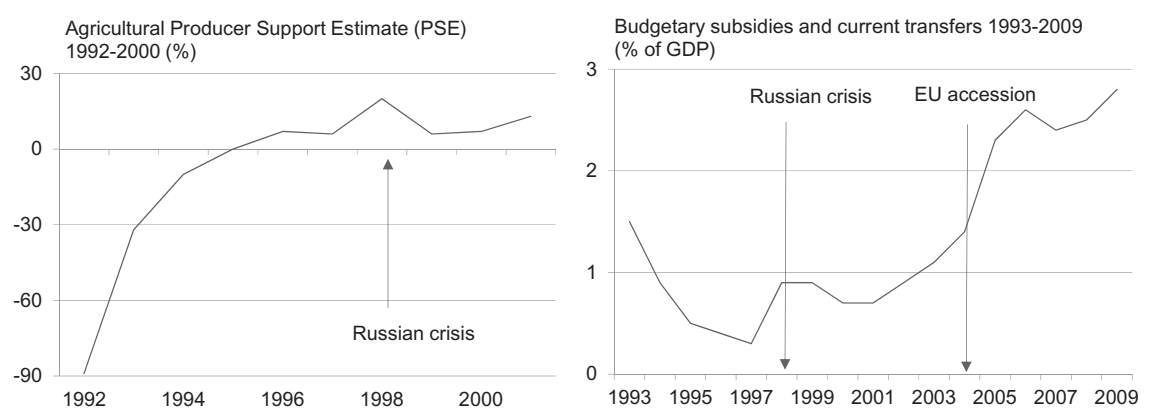

Figure 3. Industrial policy in Estonia, 1992-2009. Note: The Producer Support Estimate (PSE) measures the annual monetary value of gross transfers from consumers and taxpayers to agricultural producers, measured at the farm-gate level. Budgetary subsidies and transfers exclude social transfers. Sources: Organisation for Economic Co-operation and Development (OECD) for PSE, European Bank for Reconstruction and Development (ERBD), Transition report (years 2000, 2006 and 2010), for budgetary subsidies and transfers.

process of layering (Table 2, box C). This can be observed in four steps. First, Estonia had to give away its almost free trade regime, raise tariffs and adopt several non-tariff and quota restrictions in line with EU protections against third countries (Feldmann and Sally, 2002, p. 99). Second, Estonia had to incorporate the provisions of the CAP, which implied a steep increase in agricultural subsidies (Figure 3). Third, the pre-accession process opened up the possibility to adopt a new framework of industrial policy (Tiits et al., 2006, p. 60; Suurna and Kattel, 2010). Two public bodies were established under the idea of providing a horizontal battery of instruments promoting SMEs and exporters: Enterprise Estonia and the Credit and Export Guarantee Fund (KREDEX).

Broadening and institutionalizing these measures had two crucial outcomes: ${ }^{10}$ to familiarize state bureaucracy with the idea of selectiveness and to empower the few actors proposing more active industrial policy in the country. Thus, whereas in a first moment the new programs were strictly horizontal and restricted to the arrival of EU funds, over time government spending as well as selectiveness started to slowly increase (Tiits et al., 2006, p. 59; Suurna and Kattel, 2010). The fourth layering step echoed these developments, as it implied an increasing selectiveness in state interventions. An example is the foundation in 2006 of the Development Fund (Arengufond). The Development Fund is a publicly financed development agency in charge of making studies of prospective areas of profitable investmentincluding new industries-and channel investment into those areas. It was designed after Finland's Finnish Innovation Fund, and was decisively pushed forward by the center-left Center Party in government in 2005.

The 2007-2008 financial crisis, however, contributed to reverse these developments in industrial policy and consolidate orthodox neoliberalism in Estonia. Similarly as the crises of 1992 and 1997-1998, this turning point was tightly connected with the operation of the currency board. Following an outstanding economic boom during 2000-2005, Estonia

10 Interview with Innovation and Technology professor, Tallinn November 13, 2013. 
started to show signs of overheating and macroeconomic imbalances once again. These imbalances, especially high inflation and unsustainable current account deficits, threatened the much-expected EMU accession despite the fulfilment of the Maastricht criteria on fiscal accounts (Deroose et al., 2010; Raudla and Kattel, 2011). The crisis generated a credit crunch, depressing the housing and construction bubbles, as well as private investment and consumption with it. Estonia's output accumulated a fall of $18.9 \%$ in 2008-2009 (Raudla and Kattel, 2011, p. 163).

Despite the magnitude of the crisis, the political context for changing high-hierarchy exchange rates maintained a strong status quo bias. Prime Minister Andrus Ansip and his Reform Party insisted on the need to reinforce the currency board through a process of internal devaluation in order to maintain the confidence of external investors (Raudla and Kattel, 2011). Two key foreign actors further supported this strategy (Kuokštis and Vilpišauskas, 2010, pp. 6-7): the Swedish government and the European Commission. The former was concerned with the problems a devaluation of the Estonian kroon would bring to the Swedish banks controlling the Estonian financial sector. The latter feared that a devaluation in Estonia would force a financial collapse in East Europe. Moreover, Estonian civil society was particularly inactive in terms of protesting against the crisis and the ensuing austerity measures (Beissinger and Sasse, 2014).

Given these conditions, our framework predicts yet one more marginal adjustment in high-hierarchy institutions and evidence supports this. The first set of measures where almost identical as the last two financial crises: adjusting capital-adequacy ratios and deposit shares (Deroose et al., 2010). When this was not enough, authorities set the target of using the crisis to enter the EMU. Although the change from a currency board to the adoption of the euro might not seem a marginal adjustment at first sight, commentators note that from a monetary policy point of view Estonia had been a de facto member of the Eurozone since the pegging of the Kroon to the German Mark in the early 1990s (Sörg and Vensel, 2000, p. 133). Thanks to the decrease in inflation provoked by the recession, the maintenance of the currency board and the exchange rate parity, and a steep fiscal consolidation process, Estonia entered the Eurozone in 2011. This process reflects the strengthening of the neoliberal social bloc. In fact, from 2007 the rightist Reform Party has managed to lead all governments and keep the center-left Center Party away from government posts as well as to eschew demands by the Social Democrats (Raudla and Kattel, 2011). Moreover, FDI has become the key source of economic growth once again.

In the case of the low-hierarchy industrial policy, the political environment remained up for changes. This was reflected in the relegation of the center-left Center Party and the decrease in support and open contestation of selective measures such as the Development Fund (Baltic Business News, 2009). Moreover, even though the Development Fund was backed by a law securing permanent funding from Congress, the Reform Party-led governments did not find it particularly difficult to scale back. In fact, in 2009 the government took back and sold the Telekom shares that had been allocated to the Fund and constituted its main source of funding, therefore significantly impairing its activities. ${ }^{11}$ Additionally, the new governmentappointed management revamped the Fund's structure, significantly changing its functioning and original purposes. With low status quo bias and low barriers to internal change (Table 2, box D), this process reflects a mechanisms of displacement, that is, the 'rediscovery or

\section{Personal communication with former Board Director of the Development Fund.}


activation ... of alternative institutional forms' (Streeck and Thelen, 2005, p. 20), in this case, those imposing a neutrality bias instead of a selective one on industrial policy.

\section{Conclusions}

In this article, I have drawn on existing historical institutionalist literature to advance an explanation of neoliberal resilience. The analytical framework I propose is based on the premise that resilience requires constant change and that often dominant groups lead processes of change in order to control their outcome. The incorporation of Amable's notion of 'institutional hierarchy' into Mahoney and Thelen's theory of gradual institutional change is a good way to capture this, and provides a dynamic and politically grounded theory of institutional resilience. It allows, in fact, understanding institutional resilience in the context of constant change. One key distinction is that between high-hierarchy and low-hierarchy institutions, suggesting that there is a core of policies and institutions that dominant social blocs view as crucial. This means that change tends to be more controlled and cosmetic in highhierarchy institutions, and may be more encompassing in low-hierarchy institutions depending on the challenge dominant social blocs face from subordinated groups. The distinction between high-hierarchy and low-hierarchy institutions also provides a way to analyze and understand the distributional outcomes of simultaneous and imbricated processes of institutional change operating in related policy fields, as illustrated here with exchange rates and industrial policy.

The empirical analysis has shown that while in Estonia dominant groups have been able to institutionalize a tight neoliberal path binding the development of both exchange rate and industrial policies, in Chile they have had to surrender low-hierarchy industrial policies in order to maintain control of high-hierarchy exchange rates. Therefore, while the Estonian dominant social bloc has reinforced its commitment to neoliberalism after adopting the euro in 2011, the Chilean dominant social bloc faces increasing problems due to the need to incorporate wider business sectors and political forces into the dominant bloc in order to defend high-hierarchy institutions.

In this article, I have elaborated four mechanisms that capture the dynamics of change of resilient neoliberal trajectories like the ones observed in Chile and Estonia: marginal adjustment or parametric changes in order to improve performance, solidification or narrowing spaces for future change, and making minor (accommodation) or larger (compromise) concessions in order to placate the discontent of challenging social groups. These mechanisms, I have explained, are much institutional as they are political. On the one hand, they help understanding how changes in the correlation of forces can reinforce existing institutional compromises. On the other hand, they also illuminate how these processes may carry the seeds of more substantive changes in the future. In fact, given that each mechanism also entails the modification of the underlying political forces, specific sequences of institutional continuity can build the possibility for more substantive challenges in the future. In this sense, a historical sequence marked by mechanisms of marginal adjustment and solidification make neoliberal resilience more likely because they reinforce the institutional hierarchy and the supporting dominant social bloc. Contrariwise, the mechanisms of accommodation and compromise have contradicting outcomes. On the one hand, they release pressure for a more radical institutional overhaul by incorporating contesting groups into the dominant bloc. On the other hand, they increase the inconsistency of the institutional hierarchy 
because new groups bring interests and policy preferences that conflict with those of established groups within the dominant bloc. In this sense, as previously subordinated groups gain significance, both accommodation and compromise may lead to a more substantive moment of change in the future. This provides tools to go beyond the mere realization that neoliberalism did not die with the 2007-2008 crisis, as the existing literature tells us. A careful study of institutional reform under these premises may shed light on whether changes will actually reinforce neoliberalism in the years to come, or whether they introduce the seeds of its own destruction. In this context, the study of sequences of institutional change becomes crucial (Van der Heijden, 2010).

An under researched issue on this article has been the effect of external sources of change and their relation to domestic ones. The empirical analyses indicate that these can exert diverse degrees of leverage that reinforce neoliberalism and act as obstacles for change towards more embedding directions. Finally, further research is needed to better specify and test the proposed mechanisms of neoliberal resilience. A more systematic study of commonalities and differences in neoliberal policy trajectories combining case studies with comparative analysis would be particularly well suited.

\section{Acknowledgments}

I thank comments to this and earlier versions from Uwe Becker, Dorothee Bohle, Helen Callaghan, Antoine Maillet, James Mosher, Cristoph Nguyen, Cristóbal Rovira, the participants at the 'Social coalitions and crises' mini-conference at the SASE 2015 Annual Meeting, and two anonymous reviewers.

\section{References}

Agosín, M., Larraín, C. and Grau, N. (2009) Industrial Policy in Chile, Working Paper 294, Santiago de Chile, Department of Economics University of Chile.

Amable, B. (2003) The Diversity of Modern Capitalism, New York, Oxford University Press.

Amable, B. and Palombarini, S. (2009) 'A Neorealist Approach to Institutional Change and the Diversity of Capitalism', Socio-Economic Review, 7, 123-143.

Baltic Business News (2009, March 30) 'Estonian Development Fund - Great Boast, Small Roast' Tallinn.

Baltic News Service (1999, June 3) 'Twelve Parties Vying for Seats in Estonian Parliament', Tallinn.

Beissinger, M. R. and Sasse, G. (2014) 'An End to "Patience"? The Great Recession and Economic Protest in Eastern Europe'. In Bermeo, N. and Bartels, L. M. (eds) Mass Politics in Tough Times: Opinions, Votes, And Protest in the Great Recession, Oxford/New York, Oxford University Press, pp. 334-369.

Blyth, M. (2013) Austerity: The History of a Dangerous Idea, Oxford/New York, Oxford University Press.

Boas, T. C. (2007) 'Conceptualizing Continuity and Change', Journal of Theoretical Politics, 19, 33-54.

Bohle, D. and Greskovits B. (2007) 'Neoliberalism, Embedded Neoliberalism and Neocorporatism: Towards Transnational Capitalism in Central-Eastern Europe', West European Politics, 30, 443-466.

Boylan, D. M. (1998) 'Preemptive Strike: Central Bank Reform in Chile's Transition from Authoritarian Rule', Comparative Politics, 30, 443-462. 
Bradford C. I. Jr. (1990) 'Policy Interventions and Markets: Development Strategy Typologies and Policy Options'. In Gereffi, G. and Wyman, D. L. (eds) Manufacturing Miracles. Paths of Industrialization in Latin America and East Asia, Princeton, NJ, Princeton University Press, pp. 32-54.

Broz, L., and Frieden, J. A. (2006) 'The Political Economy of Exchange Rates'. In Weingast, B. R. and Wittman, D. A. (eds) The Oxford Handbook of Political Economy, New York, Oxford University Press, pp. 587-98.

Bubula, A., \& Ötker, I. (2002) The Evolution of Exchange Rate Regimes Since 1990; Evidence From De Facto Policies, IMF Working Paper No. 02/155. Washington DC: International Monetary Fund.

Campero, G. (1984). Los gremios empresariales en el periodo 1970-1983: comportamiento sociopolítico y orientaciones ideológicas, Santiago de Chile, Instituto Latinoamericano de Estudios Transnacionales.

Camyar, I. (2014) 'Political Parties, Supply-Side Strategies, and Firms: The Political MicroEconomy of Partisan Politics', The Journal of Politics, 76, 725-739.

Connell, R. and Dados, N. (2014) 'Where in the world does neoliberalism come from? The market agenda in southern perspective', Theory and Society, 43, 117-138.

Crouch, C. (2011) The Strange Non-Death of Neo-Liberalism, Cambridge, Polity Press.

Crouch, C., Streeck, W., Boyer, R., Amable, B., Hall, P. A. and Jackson, G. (2005), 'Dialogue on 'Institutional Complementarity and Political Economy', Socio-Economic Review, 3, 359-382.

Deroose, S., Flores, E., Giudice, G. and Turrini, A. (2010) The Tale of the Baltics: Experiences, Challenges Ahead and Main Lessons, ECFIN Economic Brief 10, Directorate-General for Economic and Financial Affairs European Commission.

Eamets, R., Varblane, U. and Sostra, K. (2003) 'External Macroeconomic Shocks and the Estonian Economy: How Did the Russian Financial Crisis Affect Estonian Unemployment and Foreign Trade?', Baltic Journal of Economics, 3, 5-24.

ECLAC (2012) Structural Change for Equality: An Integrated Approach to Development, Santiago de Chile, Economic Commission for Latin America and the Caribbean - United Nations.

Feldmann, M. (2006) 'The Baltic States: Pacesetting on EMU Accession and the Consolidation of Domestic Stability Culture'. In Dyson, K. (ed.) Enlarging the Euro Area: External Empowerment and Domestic Transformation in East Central Europe, Oxford/New York, Oxford University Press, pp. 127-143.

Feldmann, M. and Sally, R. (2002) 'From the Soviet Union to the European Union: Estonian Trade Policy, 1991-2000', World Economy, 25, 79-106.

Ffrench-Davis, R. (2003) Entre el neoliberalismo y el crecimiento con equidad: tres décadas de política económica en Chile, Santiago de Chile, LOM.

Fleming, A., Chu, L. and Bakker, M. (1996) The Baltics: Banking Crises Observed, Policy Research Working Paper 1647, Washington D.C., World Bank.

Foxley, A. (1983) Latin American Experiments in Neoconservative Economics, Berkeley, CA, University of California Press.

Frenkel, R. and Rapetti, M. (2010) A Concise History of Exchange Rate Regimes in Latin America, Washington D.C., Center for Economic and Policy Research.

Frieden, J. A., Ghezzi, P. and Stein, E. (2001) 'Politics and Exchange Rates: A Cross-Country Approach'. In Frieden, J. A. and Stein, E. (eds) The Currency Game: Exchange Rate Politics in Latin America. Washington, D.C, Inter-American Development Bank, pp. 21-63.

Hacker, J. S. (2005) 'Policy Drift: The Hidden Politics of US Welfare State Retrenchment'. In Streeck, W. and Thelen, K. (eds) Beyond Continuity: Institutional Change in Advanced Political Economies, New York, Oxford University Press, pp. 40-81.

Hall, P. A. (1993) 'Policy Paradigms, Social Learning, and the State: The Case of Economic Policymaking in Britain', Comparative Politics, 25, 275-296. 
Hall, P. A. and Lamont, M. (2013) Social Resilience in the Neoliberal Era, New York, Cambridge University Press.

Hanke, S. H. (2008) 'Friedman: Float or Fix?', Cato Journal, 28, 275-285.

Kosacoff, B. and Ramos, A. (1999) 'The Industrial Policy Debate', CEPAL Review, 68, 35-60.

Kuokštis, V., and Vilpišauskas, R. (2010) 'Economic Adjustment to the Crisis in the Baltic States in Comparative Perspective', paper presented at the 7th Pan-European International Relations Conference, Stockholm, Sweden, September.

Laar, M. (2002) Estonia: Little Country That Could, London, Centre for Research into PostCommunist Economies.

Lagerspetz, M. and Vogt, H. (2013) 'Estonia'. In Berglund, S., Ekman, J., Deegan-Krause, K. and Knuten, T. (eds) The Handbook of Political Change in Eastern Europe, Northampton, MA, Edward Elgar, pp. 51-83.

Lauristin, M. and Vihalemm, P. (1997) 'Recent Historical Developments in Estonia: Three Stages of Transition (1987-1997)'. In Rosengren, K., Lauristin M. and Vihalemm, P. (eds) Return to the Western World: Cultural and Political Perspectives on the Estonian Post-Communist Transition, Tartu, Tartu University Press, pp. 73-126.

Lefort, F. (2010) 'Business Groups in Chile'. In Colpan, A. M., Hikino, T. and Lincoln, J. R. (eds) The Oxford Handbook of Business Groups, New York, Oxford University Press, pp. 387-422.

Levitsky, S. and Murillo, M. V. (2013) 'Building Institutions on Weak Foundations', Journal of Democracy, 24, 93-107.

Mahoney, J. and Thelen, K. (2010) 'A Theory of Gradual Institutional Change'. In Mahoney, J. and Thelen, K. (eds) Explaining Institutional Change: Ambiguity, Agency, and Power, New York, Cambridge University Press, pp. 1-36.

Meller, P. (1996) Un siglo de economía política chilena (1890-1990), Santiago de Chile, Andrés Bello.

Mirowski, P. (2013) Never Let a Serious Crisis Go to Waste: How Neoliberalism Survived the Financial Meltdown, London/New York, Verso.

Morandé, F. and Tapia, M. (2002) 'Política cambiaria en Chile: el abandono de la banda y la experiencia de flotación', Economía Chilena, 5, 67-94.

Mukherjee, B., and Singer, D. A. (2008) 'Monetary Institutions, Partisanship, and Inflation Targeting', International Organization, 62, 323-358.

Muñoz Gomá, Ó. (2001) 'La economía chilena en el cambio de siglo y la estrategia de desarrollo'. In Muñoz Gomá, O. (ed.) Más allá del bosque: Transformar el modelo exportador, Santiago de Chile, FLACSO, pp. 17-65.

OECD (2000) OECD Economic Surveys: Baltic States: A Regional Economic Assessment, Paris, Organisation for Economic Co-operation and Development.

Pettai, V. and Hallik, K. (2002) 'Understanding Processes of Ethnic Control: Segmentation, Dependency and Co-optation in Post-communist Estonia', Nations and Nationalism, 8, 505-529.

Pierson, P. (2004) Politics in Time: History, Institutions, and Social Analysis, Princeton, NJ, Princeton University Press.

Raudla, R. and Kattel, R. (2011) 'Why Did Estonia Choose Fiscal Retrenchment after the 2008 Crisis?', Journal of Public Policy, 31, 163-186.

Román, E. (2003) 'El fomento productivo en una economía de mercado: Lecciones del caso chileno'. In Muñoz Gomá, O (ed.) Hacia un Chile competitivo: instituciones y politicas, Santiago, Ed. Universitaria/FLACSO, pp. 25-65.

Saad-Filho, A. (2005) 'From Washington to Post-Washington Consensus: Neoliberal Agendas for Economic Development'. In Saad-Filho, A. and Johnston, D. (eds) Neoliberalism: A Critical Reader, London/Ann Arbor, MI, Pluto Press, pp. 113-120.

Schmidt, V. A. and Thatcher, M. (2013) Resilient Liberalism in Europe's Political Economy, New York, Cambridge University Press. 
Schrank, A. and Kurtz, M. J. (2005) 'Credit Where Credit Is Due: Open Economy Industrial Policy and Export Diversification in Latin America and the Caribbean' Politics \& Society, 33, 671-702.

Seawright, J. and Gerring, J. (2008) 'Case Selection Techniques in Case Study Research: A Menu of Qualitative and Quantitative Options' Political Research Quarterly, 61, 294-308.

Silva, E. (1996) The State and Capital in Chile: Business Elites, Technocrats, and Market Economics, Boulder, CO, Westview Press.

Silva, E (2002) 'Capital and the Lagos Presidency: Business as Usual?', Bulletin of Latin American Research, 21, 339-357.

Smith, D. (2001) Estonia: Independence and European Integration, London, Routledge.

Sörg, M. and Vensel, V. (2000) 'The Currency Board in Estonia'. In Zloch-Christy, I. (ed.) Economic Policy in Eastern Europe: Were Currency Boards a Solution?, Westport, CT, Praeger Publishers.

Streeck, W. (2014) Buying Time: The Delayed Crisis of Democratic Capitalism, London/New York, Verso.

Streeck, W. and Thelen, K. (2005) 'Introduction: Institutional Change in Advanced Political Economies', In Streeck, W. and Thelen, K. (eds) Beyond Continuity: Institutional Change in Advanced Political Economies, New York, Oxford University Press, 1-39.

Steinlin, S. and Trampusch, C. (2012) 'Institutional shrinkage: The Deviant Case of Swiss Banking Secrecy’ Regulation \& Governance, 6, 242-259.

Sutela, P. (2001) Managing Capital Flows in Estonia and Latvia, BOFIT Discussion Papers 17, Helsinki, Bank of Finland Institute for Economies in Transition.

Suurna, M. and Kattel, R. (2010) 'Europeanization of Innovation Policy in Central and Eastern Europe', Science and Public Policy, 37, 646-664.

Taylor, M. (2006) From Pinochet to the 'Third Way': Neoliberalism and Social Transformation in Chile, London, Pluto Press.

Thelen, K. (2012) 'Varieties of Capitalism: Trajectories of Liberalization and the New Politics of Social Solidarity', Annual Review of Political Science, 15, 137-159.

Tiits, M., Kattel, R. and Kalvet, T. (2006) Made in Estonia, Tartu, Institute of Baltic Studies.

Van der Heijden, J. (2010) 'A Short History of Studying Incremental Institutional Change: Does Explaining Institutional Change Provide Any New Explanations?', Regulation \& Governance, 4, 230-243.

Wagner, G., Jofré, J. and Lüders, R. (2000) Economía Chilena 1810-1995. Cuentas Fiscales. PUC Economics Institute Working Paper 188, Santiago de Chile, Instituto de Economía Pontificia Universidad Católica.

Weyland, K. (1999) 'Economic Policy in Chile's New Democracy', Journal of Interamerican Studies and World Affairs, 41, 67-96.

Williamson, J. (2002) 'The Evolution of Thought on Intermediate Exchange Rate Regimes', Annals of the American Academy of Political and Social Science, 579, 73-86. 